\title{
Texture and Sensory Properties of Cream Cheese and Cholesterol-removed Cream Cheese made from Whole Milk Powder
}

\author{
Seon-Suk Jeon, Palanivel Ganesan, Youn-Sun Lee, Sang-Hun Yoo ${ }^{1}$, and Hae-Soo Kwak* \\ Department of Food Science and Technology, Sejong University, Seoul 143-747, Korea \\ ${ }^{1}$ Department of Oriental Cuisine \& Culinary Arts, Youngsan University, Busan 612-743, Korea
}

\begin{abstract}
This study was aimed to compare the texture and sensory properties of Cream cheese and cholesterol-removed Cream cheese made from the whole milk powder (CRWMP) during storage at $7^{\circ} \mathrm{C}$ for $4 \mathrm{wk}$. The cholesterol reduction by crosslinked $\beta$-CD was about $92 \%$ in CRWMP. In texture studies, hardness, gumminess, and chewiness had increased during the storage period of $4 \mathrm{wk}$ in both cheeses, irrespective of treatment. In the sensory properties, cooked milk flavor was found to have decreased, whereas sourness had increased with increasing storage period of $4 \mathrm{wk}$ in whole milk powder Cream cheese. On the basis of our results, we conclude that the cholesterol removal in CRWMP does not cause any adverse effect on the texture and sensory properties of Cream cheese made with whole milk powder.
\end{abstract}

Key words: Cream cheese, whole milk powder, texture, sensory

\section{Introduction}

Cream cheese is one of the most popular non-ripened cheeses consumed in many developed countries and it is normally produced from the fresh whole milk (SchulzCollins and Senge, 2004). It is mostly spreadable which contains high moisture, fat, and lack of compact protein matrix (Laverse et al., 2011). Traditionally Cream cheese production is made with bovine milk and consumed within a month production. However, the Cream cheese production from other milk source and milk powders are still in a budding stage. Milk powders are used as an important ingredient in the manufacture of wide range of foods such as coffee whiteners, chocolates, desserts, and concentrated milks (Jo et al., 2010; Oldfield et al., 2000). It is also used as alternative reconstituted milk in many tropical and developing countries where domestic production is not enough to respond to the demands of the population (Granda-Restrepo et al., 2009). Since the milk powders have longer shelf life about six months for whole milk powder (Celestino et al., 1997) and the Cream cheese production from the whole milk powder

*Corresponding author: Hae-Soo Kwak, Department of Food Science and Technology, Sejong University, Seoul 143-747, Korea. Tel: 82-2-3408-3226, Fax: 82-2-3408-4319, E-mail: kwakhs@sejong.ac.kr will be an alternative new food product from the milk powder.

The milk powders are heat treated, most of the compositions of milk will be chemically and/or physically affected such as protein denaturation, fat structure loss, lactose decomposition, vitamin loss, and cooked flavor (Webb et al., 1983). The proteolytic and lipolytic breakdown of milk components by heat treatments may cause the production of soft curds and leads to limited production hard and semi-hard cheese with milk powder but we assume soft or semi-soft cheese making may be possible such as Cream cheese. Further healthier eating habits increase the demand of lower cholesterol dairy products such as cheese, butter and cream in the market (Ahn and Kwak, 1999) and no information is available on the effect of cholesterol removal by crosslinked $\beta-\mathrm{CD}$ with regard to texture and sensory characteristics of Cream cheese made from whole milk powder. Therefore, the main objective of this study was to compare texture and sensory properties of Cream cheese and cholesterol-removed Cream cheese made from whole milk powder during 4 wk storage.

\section{Materials and Methods}

\section{Materials}

Whole milk powder and cream ( $40 \%$ milk fat) were 
obtained from Seoul Dairy Co-op. (Korea). All solvents were of gas-chromatographic grade. Cholesterol and $5 \alpha-$ cholestane were purchased from Sigma Chemical Co. (USA), and all solvents were of gas-chromatographic grade.

\section{Manufacture of Cream cheese}

Cream cheese was produced according to the modified method of Kosikowski and Mistry (1997) and the cholesterol-removed Cream cheese from whole milk powder (CRWMP) was made by the following method. The whole milk powder was reconstituted to $87 \%$ water and blended with cream $(40 \%$ milk fat) to a fat content of $11 \%$ which was then pasteurized at $65^{\circ} \mathrm{C}$ for $30 \mathrm{~min}$. The mixture was stirred with $3.6 \%$ crosslinked $\beta-\mathrm{CD}$ at 800 rpm with a blender (Tops, Misung Co., Korea) in a temperature-controlled water bath at $20^{\circ} \mathrm{C}$ for $30 \mathrm{~min}$. It was then centrifuged at $166 \times \mathrm{g}$ for the $\beta-\mathrm{CD}$ removal. Cholesterol-removed mixture was homogenized (680 psi at $50^{\circ} \mathrm{C}$ ) and cooled to the incubation temperature of approximately $30^{\circ} \mathrm{C}$. The mixture was then inoculated with a $0.05 \%$ lactic culture (CNN-22, Chr. Hansen's Lab., Denmark) and incubated under gentle mixing. The curd was cut and ripened for $7 \mathrm{~h}$ to $\mathrm{pH}$ of 4.7. Then it was heated in a coil vats to about $45^{\circ} \mathrm{C}$ until a proper "break" is obtained between the curd and the whey. Whey was drained and the curd was cooled to $28^{\circ} \mathrm{C}$ for $4 \mathrm{~h}$ with continuous turning. The curd was drained in muslin bags and pressed until the curd TS was $45 \%$ and stored in plastic tubs at $7^{\circ} \mathrm{C}$ for $4 \mathrm{wk}$. The whole milk powder and cream without treating with the $\beta-\mathrm{CD}$ was used as the Cream cheese.

\section{Composition}

Cream cheeses were analyzed for moisture, protein and fat according to the methods of the Association of Official Analytical Chemists (AOAC, 1984).

\section{Extraction of cholesterol}

Cholesterol from Cream cheeses was extracted according to the method of Lee et al. (1999). One g of sample was placed in a screw-capped glass tube $(15 \mathrm{~mm} \times 180$ $\mathrm{mm})$, and $500 \mu \mathrm{L}$ of $5 \alpha$-cholestane $(1 \mathrm{mg} / \mathrm{mL})$ was added as an internal standard. The sample was saponified at $60^{\circ} \mathrm{C}$ for 30 min with $5 \mathrm{~mL}$ of $2 \mathrm{M}$ ethanolic potassium hydroxide solution (Adams et al., 1986). After cooling to room temperature, cholesterol was extracted with $5 \mathrm{~mL}$ of hexane. The process was repeated four times. The hexane layers were transferred to a round-bottomed flask and dried under vacuum. The extract was redissolved in $1 \mathrm{~mL}$ of hexane and stored at $20^{\circ} \mathrm{C}$ until analysis.

\section{Determination of cholesterol}

Cholesterol was determined on a silica fused capillary column (HP-5, $30 \mathrm{~m} \times 0.32 \mathrm{~mm}$ I.D. $\times 0.25 \mu \mathrm{m}$ thickness) using a Hewlett-Packard 5890 A gas chromatograph (Hewlett-Packard, USA) equipped with a flame ionization detector. The temperatures of injector and detector were 270 and $300^{\circ} \mathrm{C}$, respectively. The oven temperatures were programmed from 200 to $300^{\circ} \mathrm{C}$ at $10^{\circ} \mathrm{C} / \mathrm{min}$ and held for $20 \mathrm{~min}$. Nitrogen was used as a carrier gas at a flow rate of $2 \mathrm{~mL} / \mathrm{min}$ with a split ratio of 1:50. Quantification of cholesterol was performed by comparing the peak areas with the response from an internal standard. The percentage of cholesterol reduction was calculated as follows: cholesterol reduction $(\%)=100-$ (amount of cholesterol in $\beta$-CD-treated Cream cheese $\times 100$ /amount of cholesterol in Cream cheese). Cholesterol determination for Cream cheese was averaged with each batch of treatments.

\section{Texture}

Texture analysis of Cream cheese was performed with a TA-XT2i texture analyzer (Stable Micro Systems, England). Prior to analysis, Cream cheeses prepared in a rectangular shape $(25 \times 30 \times 10 \mathrm{~mm})$ were wrapped in a plastic film and tempered at $10^{\circ} \mathrm{C}$ for $20 \mathrm{~min}$. The samples were compressed twice to $50 \%$ of their original height with a compression flat headed plunger $(20 \mathrm{~mm}$ diameter) at a constant rate of $1 \mathrm{~mm} / \mathrm{s}$. Textural analyses were performed at room temperature. Hardness $(\mathrm{N})$, springiness $\left(\mathrm{m} \times 10^{-3}\right)$, cohesiveness $(\mathrm{J})$, gumminess $(\mathrm{N})$ and chewiness $\left(\mathrm{J} \times 10^{-3}\right)$ were evaluated. These parameters were obtained from the MicroStable Software (England) with the average of six measurements.

\section{Sensory evaluation}

Sensory characteristics of Cream cheese during ripening at $7^{\circ} \mathrm{C}$ for 4 wk were studied using a quantitative descriptive analysis carried out by a panel of ten selected and trained assessors. Panel was consisted of experienced ten panelists (five females and five males) from the academic staff working in the Food Technology Department, Sejong University. Panel evaluated cheeses in terms of appearance, odor, texture, and taste properties during storage. The panel was trained $1 \mathrm{~h}$ before each evaluation session. Some sensory terms for flavor-aroma and texture of cheeses were introduced to panelists. Samples were 
served with a glass of water and an unsalted cracker to the panelists after they were left at the room temperature for $10 \mathrm{~min}$. Sample was presented in 3 digit-coded glass plates and presented at the same time in each session. Sensory evaluation of sample in each analysis period was carried out two times.

\section{Statistical analysis}

All statistical analyses were performed using SAS version 9.0 (SAS Institute, 2002). An ANOVA was performed using the general linear models procedure to determine significant differences among the samples. Means were compared by using Duncan's multiple range test $(p<$ $0.05)$.

\section{Results and Discussion}

\section{Chemical composition}

The protein, fat, and moisture content showed similar ratio between Cream cheese and CRWMP and are shown in Table 1. Similar properties were also seen in the Cream cheese made from whole milk (Kosikowski and Mistry, 1997) and whole milk powder, and also cholesterolremoved Cream cheese made from whole milk (Han et al., 2008) and whole milk powder. The cholesterol content of the whole milk powdered Cream cheese was 96.28 $\mathrm{mg} / 100 \mathrm{~g}$. The removal rate of cholesterol by crosslinked $\beta-C D$ in CRWMP was found to be about $92.8 \%$. Similar cholesterol removals were also found in Blue cheese by crosslinked $\beta-C D$ without any significant change in the color and sensory properties (Kim et al., 2008). It con-
Table 1. Chemical compositions of Cream cheese and cholesterol-removed Cream cheese made from whole milk powder

\begin{tabular}{lcc}
\hline \multicolumn{1}{c}{ Components } & Cream cheese & CRWMP $^{1)}$ \\
\hline Moisture (\%) & $58.30 \pm 0.29$ & $58.50 \pm 0.50$ \\
Protein (\%) & $7.97 \pm 0.10$ & $7.96 \pm 0.12$ \\
Fat (\%) & $33.68 \pm 0.11$ & $33.53 \pm 0.11$ \\
Cheese yield (\%) & 36.2 & 36.2 \\
Cholesterol (mg/100g) & 96.28 & 7.47 \\
Cholesterol removal (\%) & - & 92.8 \\
\hline
\end{tabular}

${ }^{1)}$ CRWMP, cholesterol-removed Cream cheese made from whole milk powder

firms that cholesterol removal by crosslinked $\beta-C D$ does not effect the approximate composition of the Cream cheese.

\section{Texture}

Textural properties of the whole milk-powdered Cream cheese and CRWMP stored at $7^{\circ} \mathrm{C}$ for $4 \mathrm{wk}$ were presented in Table 2. Hardness value of both cheeses reached maximum at $4 \mathrm{wk}$ of storage and it could be explained by the fact of reduced level of moisture and increased total solids during storage period of $4 \mathrm{wk}$. Some researchers also reported that high fat Cream cheese increased its hardness due to its higher fat content as after homogenisation, fat globules are partly covered with casein and participate in the aggregation of casein particles reinforcing the structure of these products (Brighenti et al., 2008; Lucey et al., 1998). In the both samples, cohesiveness and springiness did not show any significant changes over the 4 wk storage $(p>0.05)$. In contrast, some researchers

Table 2. Textural analysis of Cream cheese and cholesterol-removed Cream cheese made from whole milk powder during storage at $7^{\circ} \mathrm{C}$ for 4 wk $^{1)}$

\begin{tabular}{|c|c|c|c|c|c|c|}
\hline \multirow{2}{*}{ Treatment } & \multirow{2}{*}{ Texture } & \multicolumn{5}{|c|}{ Storage period (wk) } \\
\hline & & 0 & 1 & 2 & 3 & 4 \\
\hline \multirow{2}{*}{$\begin{array}{l}\text { Cream cheese } \\
\text { CRWMP }^{4}\end{array}$} & \multirow{2}{*}{$\begin{array}{c}\text { Hardness } \\
\left(\mathrm{N}^{2)}\right)\end{array}$} & $0.57 \pm 0.04^{\mathrm{d}}$ & $0.89 \pm 0.10^{\mathrm{c}}$ & $1.01 \pm 0.02^{b}$ & $1.54 \pm 0.05^{\mathrm{a}}$ & $1.62 \pm 0.06^{\mathrm{a}}$ \\
\hline & & $0.57 \pm 0.04^{b}$ & $0.70 \pm 0.03^{b}$ & $0.91 \pm 0.07^{\mathrm{b}}$ & $1.25 \pm 0.05^{\mathrm{a}}$ & $1.50 \pm 0.39^{\mathrm{a}}$ \\
\hline \multirow{2}{*}{$\begin{array}{l}\text { Cream cheese } \\
\text { CRWMP }\end{array}$} & \multirow{2}{*}{$\begin{array}{l}\text { Cohesiveness } \\
\qquad\left(\mathrm{J}^{3)}\right)\end{array}$} & $0.78 \pm 0.01^{\mathrm{a}}$ & $0.71 \pm 0.01^{\mathrm{b}}$ & $0.66 \pm 0.01^{\mathrm{c}}$ & $0.70 \pm 0.05^{\mathrm{bc}}$ & $0.72 \pm 0.02^{b}$ \\
\hline & & $0.79 \pm 0.01^{\mathrm{a}}$ & $0.76 \pm 0.04^{\mathrm{ab}}$ & $0.71 \pm 0.06^{\mathrm{b}}$ & $0.74 \pm 0.05^{\mathrm{ab}}$ & $0.74 \pm 0.01^{\mathrm{ab}}$ \\
\hline \multirow{2}{*}{$\begin{array}{l}\text { Cream cheese } \\
\text { CRWMP }\end{array}$} & \multirow{2}{*}{$\begin{array}{l}\text { Springiness } \\
\left(\mathrm{m} \times 10^{-3}\right)\end{array}$} & $24.15 \pm 0.53^{b}$ & $24.56 \pm 0.35^{\mathrm{ab}}$ & $24.77 \pm 0.18^{\mathrm{a}}$ & $24.67 \pm 0.05^{\mathrm{ab}}$ & $24.59 \pm 0.03^{\mathrm{ab}}$ \\
\hline & & $23.78 \pm 0.71^{\mathrm{b}}$ & $24.54 \pm 0.04^{\mathrm{a}}$ & $24.72 \pm 0.15^{\mathrm{a}}$ & $24.60 \pm 0.05^{\mathrm{a}}$ & $24.56 \pm 0.03^{\mathrm{a}}$ \\
\hline \multirow{2}{*}{$\begin{array}{l}\text { Cream cheese } \\
\text { CRWMP }\end{array}$} & \multirow{2}{*}{ Gumminess (N) } & $0.45 \pm 0.04^{\mathrm{d}}$ & $0.63 \pm 0.07^{\mathrm{c}}$ & $0.87 \pm 0.11^{\mathrm{b}}$ & $1.05 \pm 0.05^{\mathrm{a}}$ & $1.11 \pm 0.01^{\mathrm{a}}$ \\
\hline & & $0.55 \pm 0.06^{\mathrm{c}}$ & $0.53 \pm 0.01^{\mathrm{c}}$ & $0.82 \pm 0.05^{\mathrm{b}}$ & $0.93 \pm 0.05^{\mathrm{ab}}$ & $1.12 \pm 0.28^{\mathrm{a}}$ \\
\hline \multirow{2}{*}{$\begin{array}{l}\text { Cream cheese } \\
\text { CRWMP }\end{array}$} & \multirow{2}{*}{$\begin{array}{l}\text { Chewiness } \\
\left(\mathrm{J} \times 10^{-3}\right)\end{array}$} & $10.76 \pm 0.61^{\mathrm{d}}$ & $15.38 \pm 1.52^{\mathrm{c}}$ & $21.64 \pm 2.84^{b}$ & $25.86 \pm 0.05^{\mathrm{a}}$ & $27.34 \pm 0.23^{\mathrm{a}}$ \\
\hline & & $13.11 \pm 1.80^{\mathrm{c}}$ & $12.97 \pm 0.30^{\mathrm{c}}$ & $20.54 \pm 0.68^{b}$ & $22.86 \pm 0.05^{\mathrm{ab}}$ & $27.50 \pm 0.91^{\mathrm{a}}$ \\
\hline
\end{tabular}

\footnotetext{
${ }^{1)}$ Values with different letters within the same row differ significantly $(p<0.05)$.

${ }^{2)} \mathrm{N}$, newton

${ }^{3)}$ J, Joule
}

${ }^{4)}$ CRWMP, cholesterol-removed Cream cheese made from whole milk powder 
Table 3. Sensory properties of Cream cheese and cholesterol-removed Cream cheese made from whole milk powder during storage at $7^{\circ} \mathrm{C}$ for $4 \mathrm{wk}^{1)}$

\begin{tabular}{|c|c|c|c|c|c|c|c|}
\hline \multirow{2}{*}{\multicolumn{2}{|c|}{ Sensory }} & \multirow{4}{*}{\begin{tabular}{l}
\multicolumn{1}{c}{ Treatment } \\
Cream cheese \\
CRWMP $^{2)}$
\end{tabular}} & \multicolumn{5}{|c|}{ Storage period (wk) } \\
\hline & & & 0 & 1 & 2 & 3 & 4 \\
\hline \multirow{2}{*}{ Appearance } & \multirow{2}{*}{ Creamy white } & & $6.58^{\mathrm{a}}$ & $6.61^{\mathrm{a}}$ & $6.82^{\mathrm{a}}$ & $6.87^{\mathrm{a}}$ & $6.89^{\mathrm{a}}$ \\
\hline & & & $6.55^{\mathrm{b}}$ & $6.66^{\mathrm{ab}}$ & $6.84^{\mathrm{ab}}$ & $6.89^{\mathrm{a}}$ & $6.91^{\mathrm{a}}$ \\
\hline \multirow{2}{*}{ Flavor } & \multirow{2}{*}{ Cooked } & Cream cheese & $6.53^{\mathrm{a}}$ & $6.47^{\mathrm{ab}}$ & $6.37^{\mathrm{ab}}$ & $6.22^{\mathrm{ab}}$ & $6.17^{b}$ \\
\hline & & CRWMP & $6.42^{\mathrm{a}}$ & $6.39^{\mathrm{a}}$ & $6.24^{\mathrm{a}}$ & $6.21^{\mathrm{a}}$ & $6.15^{\mathrm{a}}$ \\
\hline \multirow{2}{*}{ Taste } & \multirow{2}{*}{ Sourness } & Cream cheese & $5.05^{\mathrm{b}}$ & $5.28^{\mathrm{ab}}$ & $5.38^{\mathrm{ab}}$ & $5.76^{\mathrm{a}}$ & $5.82^{\mathrm{a}}$ \\
\hline & & CRWMP & $5.08^{\mathrm{a}}$ & $5.23^{\mathrm{a}}$ & $5.35^{\mathrm{a}}$ & $5.68^{\mathrm{a}}$ & $5.71^{\mathrm{a}}$ \\
\hline \multirow{6}{*}{$\begin{array}{l}\text { Texture by } \\
\text { mouth feel }\end{array}$} & \multirow{2}{*}{ Granularity } & Cream cheese & $2.42^{\mathrm{a}}$ & $2.37^{\mathrm{a}}$ & $2.32^{\mathrm{a}}$ & $2.03^{\mathrm{a}}$ & $1.89^{\mathrm{a}}$ \\
\hline & & CRWMP & $2.26^{\mathrm{a}}$ & $2.21^{\mathrm{a}}$ & $1.95^{\mathrm{ab}}$ & $1.68^{\mathrm{bc}}$ & $1.50^{\mathrm{c}}$ \\
\hline & \multirow{2}{*}{ Creamy } & Cream cheese & $6.46^{\mathrm{a}}$ & $6.47^{\mathrm{a}}$ & $6.50^{\mathrm{a}}$ & $6.53^{\mathrm{a}}$ & $6.71^{\mathrm{a}}$ \\
\hline & & CRWMP & $5.45^{\mathrm{b}}$ & $5.63^{\mathrm{b}}$ & $5.71^{\mathrm{ab}}$ & $5.87^{\mathrm{ab}}$ & $5.93^{\mathrm{a}}$ \\
\hline & \multirow{2}{*}{ Softness } & Cream cheese & $7.34^{\mathrm{a}}$ & $7.32^{\mathrm{a}}$ & $7.26^{\mathrm{a}}$ & $7.18^{\mathrm{a}}$ & $6.95^{\mathrm{a}}$ \\
\hline & & CRWMP & $6.97^{\mathrm{a}}$ & $6.89^{\mathrm{a}}$ & $6.61^{\mathrm{ab}}$ & $6.32^{\mathrm{ab}}$ & $6.00^{\mathrm{c}}$ \\
\hline \multirow{2}{*}{ Texture by hand } & \multirow{2}{*}{ Spreadabilty } & Cream cheese & $6.95^{\mathrm{a}}$ & $7.18^{\mathrm{a}}$ & $7.26^{\mathrm{a}}$ & $7.32^{\mathrm{a}}$ & $7.34^{\mathrm{a}}$ \\
\hline & & CRWMP & $6.96^{\mathrm{a}}$ & $7.21^{\mathrm{a}}$ & $7.29^{\mathrm{a}}$ & $7.32^{\mathrm{a}}$ & $7.37^{\mathrm{a}}$ \\
\hline
\end{tabular}

${ }^{1)}$ Values with different letters within the same row differ significantly $(p<0.05)$.

${ }^{2)}$ CRWMP, cholesterol-removed Cream cheese made from whole milk powder

also reported that cohesiveness of whole milk Cream cheese decreased during storage (Han et al., 2008). Gumminess values in the Cream cheese and CRWMP were initially 0.45 and 0.55 , and increased to 1.11 and 1.12 , respectively after $4 \mathrm{wk}$ storage. A similar trend was also found in chewiness. In the five textural properties measured over $4 \mathrm{wk}$, there were no significant differences between the Cream cheese and CRWMP $(p>0.05)$. The present results indicated that the CRWMP showed similar textural properties comparing to those in the Cream cheese made from whole milk powder. It confirms that cholesterol removal does not have much effect on the textural properties of Cream cheeses made from whole milk powder.

\section{Sensory profiles}

The sensory attributes of whole milk-powdered Cream cheese and CRWMP stored at $7^{\circ} \mathrm{C}$ for 4 wk were presented in Table 3 . The sensory profiles, such as creamy white, granularity, creamy, softness and spreadability in Cream cheese were not found to be significantly different with increased storage period of $4 \mathrm{wk}(p>0.05)$. However, cooked milk flavor was found to decrease where as sourness was found to be significantly increase with increase storage period of $4 \mathrm{wk}$ in whole milk-powdered Cream cheese $(p<0.05)$. The increase in sourness is most likely due to the production of short-chain fatty acids (SCFFA). The SCFFA production increase likely due to the increase in lipolysis that lead to the sourness and flavor to the Cream cheese with increase storage time (Carunchia Whetstine et al., 2006). The sensory profiles of CRWMP cheese showed slightly different characteristics from Cream cheese except in spreadability. The granularity was decreased after 4 wk storage, thus CRWMP became softer after $4 \mathrm{wk}$ storage, which is desirable. Overall sensory characteristics were not much different between the Cream cheese and CRWMP. Thus cholesterol removal in the cheese doesn't affect the sensory properties of cheese during storage of $4 \mathrm{wk}$.

\section{Conclusions}

The present study suggests that whole milk powder can be effectively used for the production of Cream cheese with similar texture and sensory properties of the cheese. In addition, cholesterol removal did not cause any appropriate change in the texture and sensory of Cream cheese. Thus, this study confirms that whole milk powder blended with cream is very effective in the making of Cream cheese.

\section{Acknowledgments}

This research was supported by the Brain Korea 21 Project in Seoul, Republic of Korea. 


\section{References}

1. Adams, M. L., Sullivan, D. M., Smith, R. L., and Richer, E. F. (1986) Evaluation of direct saponification method in determination of cholesterol in meats. J. Assoc. Off. Anal. Chem. 69, 844-846.

2. Ahn, J. and Kwak, H. S. (1999) Optimizing cholesterol removal in cream using $\beta$-cyclodextrin and response surface methodology. J. Food Sci. 64, 629-632.

3. AOAC (1984) Official Methods of Analysis, 15th ed, Association of Official Analytical Chemists, Washington, DC, USA.

4. Brighenti, M., Govindasamy-Lucey, S., Lim, K., Nelson, K., and Lucey, J. A. (2008) Characterization of the rheological, textural, and sensory properties of samples of commercial US cream cheese with different fat contents. J. Dairy Sci. 91, 4501-4517.

5. Carunchia Whetstine, M. E., Drake, M. A., Nelson, B. K., and Barbano, D. (2006) Flavor profiles of full fat, reduced fat and cheese fat made from aged Cheddar with the fat removed using a novel process. J. Dairy Sci. 89, 505-517.

6. Celestino, E. L., Iyer, M., and Roginski, H. (1997) The effects of refrigerated storage of raw milk on the quality of whole milk powder stored for different periods. Int. Dairy J. 7, 119-127.

7. Granda-Restrepo, D., Peralta, E., Troncoso-Rojas, R., and Soto-Valdez, H. (2009) Release of antioxidants from coextruded active packaging developed for whole milk powder. Int. Dairy J. 19, 481-488.

8. Han, E. M., Kim, S. H., Ahn, J., and Kwak, H. S. (2008) Comparison of cholesterol-reduced cream cheese manufactured using crosslinked $\beta$-cyclodextrin to regular cream cheese. Asian Austral. J. Anim. 21, 131-137.

9. Jo, A. R., Noh, H.W., Kim, K. S., Chung, K. H., and Jeon, W. M. (2010) The development of imitated cheese using whole milk powder and fermented milk. Korean J. Food Sci. Ani. Resour. 30, 102-109.

10. Kim, H. Y., Bae, H. Y., and Kwak, H. S. (2008) Development of cholesterol-reduced blue cheese made by crosslinked $\beta$ cyclodextrin. Milchwissenschaft, 63, 53-56.

11. Kosikowski, F. V. and Mistry, V. V. (1997) Procedures and analyses In: Cheese and fermented milk foods, Kosikowski, F. V. (ed), Westport, CT, pp. 43-49.

12. Laverse, J., Mastromatteo, M., Frisullo, P., and Del Nobile, M. A. (2011) X-ray microtomography to study the microstructure of cream cheese-type products. J. Dairy Sci. 94, 4350 .

13. Lee, D. K., Ahn, J., and Kwak, H. S. (1999) Cholesterol removal from homogenized milk with $\beta$-cyclodextrin. $J$. Dairy Sci. 82, 2327-2330.

14. Lucey, J. A., Munro, P. A., and Singh, H. (1998) Rheological properties and microstructure of acid milk gels as affected by fat content and heat treatment. J. Food Sci. 63, 660-664.

15. Oldfield, D. J., Teehan, C. M., and Kelly, P. M. (2000) The effect of preheat treatment and other process parameters on the coffee stability of instant whole milk powder. Int. Dairy J. 10, 659-667.

16. SAS Institute (2002) SAS for Windows. Release 9.0, SAS Institute Inc., Cary, NC, USA.

17. Schulz-Collins, D. and Senge. B. (2004) Acid and acid/rennet-curd cheeses. Part A: Quark, cream cheese and related varieties. In: Cheese Chemistry, Physics and Microbiology Elsevier Science \& Technology, London, UK, pp. 301-328.

18. Webb, B. H., Johnson, A. H., and Alford, J. A. (1983) Fundamentals of dairy chemistry, The AVI Publishing Company, Westport, CT, USA.

(Received 2011.8.4/Revised 1st 2011.11.17, 2nd 2011.12.1, 3rd 2012.1.20/Accepted 2012.1.25) 